Vol.45, n. 4 : pp. 465-471, December 2002 ISSN 1516-8913 Printed in Brazil

\title{
Immature Culicidae (Diptera) Collected from the Igapó Lake Located in the Urban area of Londrina, Paraná, Brazil
}

\author{
José Lopes $^{1 *}$, João A. C. Zequi ${ }^{2}$, Valdecir Nunes ${ }^{3}$, Osmar de Oliveira ${ }^{3}$, Bertolino P. de O. \\ Neto $^{3}$ and Walter Rodrigues ${ }^{3}$ \\ ${ }^{1}$ Departamento de Biologia Animal e Vegetal; Universidade Estadual de Londrina; C. P. 6001; 86051-970; \\ Londrina - PR - Brazil. ${ }^{2}$ Departamento de Agronomia; Universidade Estadual de Londrina; Londrina - PR - \\ Brazil. ${ }^{3}$ Fundação Nacional de Saúde; $17^{\circ}$ Regional; Londrina - PR - Brazil
}

\begin{abstract}
The Igapó lake dam is located in an urban area in Londrina, Paraná, Brazil. A one year study of the Culicidae immature forms was conducted in this ecosystem. From a total of 962 collected larvae following genera were identified: Anopheles(59.36\%), Culex (19.65\%) Aedeomyia (19.23\%) Aedes (1.50\%), and Uranotaenia (0.10\%). The 10 most abundant species were Anopheles strodei, Aedeomyia squamipennis, Culex (Melanoconium) spp., Culex mollis, Anopheles oswaldoi, Anopheles evansae, Culex coronator, Culex quinquefasciatus, Anopheles argyritarsis and Aedes terrens respectively. An. strodei prevailed with greater averages during July and September, showing a significant negative lineal correlation in relation to the rainfall. Ad. squamipennis showed a positive lineal correlation with the temperature with smaller population averages during June, August and September of 1997. Cx. (Melanoconium) spp. populations were constant throughout the year. High Culicidae population density could bring problems to quality of human life, thus strong measures to avoid and control of mosquito population growth in the lake are recommended.
\end{abstract}

Key words: Immature Culicidae, lake, larvae

\section{INTRODUCTION}

Entire or part of animal populations with the genetic potential for adapting to degradable environments are influenced by representative artificial environmental transformations, which approximate them to human populations (Lopes and Lozovei, 1996). The construction of dams, for instance, has resulted in flooded areas developed for the generation of electric power, which may serve as breeders for many vectorial Culicidae of pathogenic agents (Guimarães et al., 1997). Natural or artificial lakes are usually eutrophic environments with the essential nutrients such as phosphate, potassium, and iron, which cause the growth of floating macrophytes, thus increasing extensively the number breeding sites of different species of mosquitoes (Quintero et al., 1996). This type of environment allows the creation of Anopheles Meigen 1818, Coquillettidia Dyar 1905, Mansonia Blanchard 1901 and Culex Linnaeus 1758 (Lopes and Lozovei, 1995).

\footnotetext{
*Author for correspondence
} 
Studies about the behavior of the fauna of Culicidae have been carried out before, during and after the development of lakes through the construction of dams Consolim et al., 1991, Quintero et al. 1996, Tadei and Thatcher (2000). Mosquitoes of 14 genera [66 species, mostly Anopheles (Nyssorhynchus) and Aedes (Ochlerotatus)] were collected (human baits) in the Itaipu power plant dam and at the mouth of the the Iguaçu river (Consolim et al., 1993). The Culicidae Anopheles strodei, Root 1926, among others, were captured in small dams and swamps in the city of Curitiba, Paraná and surrounding areas (Lozovei and Luz, 1976). Aedeomyia squamipennis (Lynch Arribalzaga) 1878 was collected in these environments in the spring and summer only, but they were present in small numbers throughout the year in the small dams.

Lopes and Lozovei, 1995 found in the São Domingos stream, in Northern Paraná, 18 species (the highest density level of Culicidae larvae), six being exclusive of that specific site, in a collection point where there used to be a dam. The $A d$. squamipennis species prevailed ( $48 \%)$ with $99.7 \%$ of its total being captured at the dam. The An. strodei was the most frequently collected species found along the river.

The objective of this research was identify the Culicidae species that procreate sites in urban artificial lakes.

\section{MATERIALS AND METHODS}

Study site: The collections were carried out in Londrina, Paraná, Brazil (Latitude $50^{\circ} 52^{\prime} 23^{\prime \prime}$ and $23^{\circ} 55^{\prime} 46^{\prime \prime S}$ and Longitude $50^{\circ} 52^{\prime} 23$ " and $51^{\circ} 19^{\prime} 11^{\prime \prime} \mathrm{W}$, average altitude 576 meters). The climate is subtropical, with rain throughout the seasons. The annual average temperature is $20.9^{\circ}$ $\mathrm{C}$ and the average rainfall index was 1630.4 millimeters / year in the period from 1976 to 1999. Lake Igapó is a $5 \mathrm{~km}$ long and in mean $800 \mathrm{~m}$ wide artificial urban lake divided by small dams into four lakes: Igapó I, II, III and IV (Fig.1). The lake is used for leisure activities, fishing and water sports. The margins of lakes II, III are covered with vegetation.

Sampling: The collections took place each other week from September 1996 to September 1997. Five collection points were selected along the
Igapó II right margin and one point along Igapó III (Fig.1). The immatures were collected using an entomological net for aquatic insects (Lopes and Lozovei, 1995). At each point, a sample from two net throwings was collected and larvae of the $3^{\text {rd }}$ and $4^{\text {th }}$ stages and pupas were selected.

One immature larvae was put in a $50 \mathrm{ml}$ plastic cup filled with water from the lake. The exuviae was displayed in Canadian balm for further comparative identification with its respective adult. The remaining $4^{\text {th }}$ stage larvae were fixed in $70 \%$ alcohol and placed between sheets using the Hoyer's liquid for identification. Pupas were maintained alive until they reached the adult phase.

Treatment statistical: Data were transformed using $(x+0.5)^{1 / 2}$. Analysis of variance and Tukey test were performed; and the lineal correlation was at the $5 \%$ level of significance. The meteorological data were obtained from the Agronomy Institute of Paraná (Instituto Agronômico do Paraná).

\section{RESULTS AND DISCUSSION}

Culicidae immatures $(n=962)$ were collected and distributed in five genera and 18 species (Table 1). Anopheles genus prevailed $[\mathrm{n}=571(59.36 \%)]$; Culex Linnaeus 1758 was the second most frequent genus $[\mathrm{n}=189(19.65 \%)]$, followed by Aedeomyia Theobald 1901 [ $\mathrm{n}=185$ (19.23\%)], Aedes $[\mathrm{n}=15(1.50 \%)]$ and Uranotaenia Lynch Arribalzaga 1878 [ $\mathrm{n}=1(0.10 \%)]$. Anopheles genus predominance $(96.8 \%)$ was also observed in areas of the Itaipu power plant (Guimarães et al., 1997). In the same area, increasing populations of An. darlingi were found during the development of the lake (Consolim et al., 1991). Changes in the mosquitoes species were found during and after the construction of the Tucurui, Pará state and Balbina power plants in the Amazonas state.

In Balbina, Nyssorhynchus subgenus (mostly $A n$. nuneztovari and An. triannulatus) was abundant whereas the An. intermedius was reduced or simply disappeared. In the Balbina dam, some species that had not been registered for the area, as the An. braziliensis, collected five years after the filling up of the lake in Tucuruí, Pará, were also found (Tadei and Thatcher, 2000). 


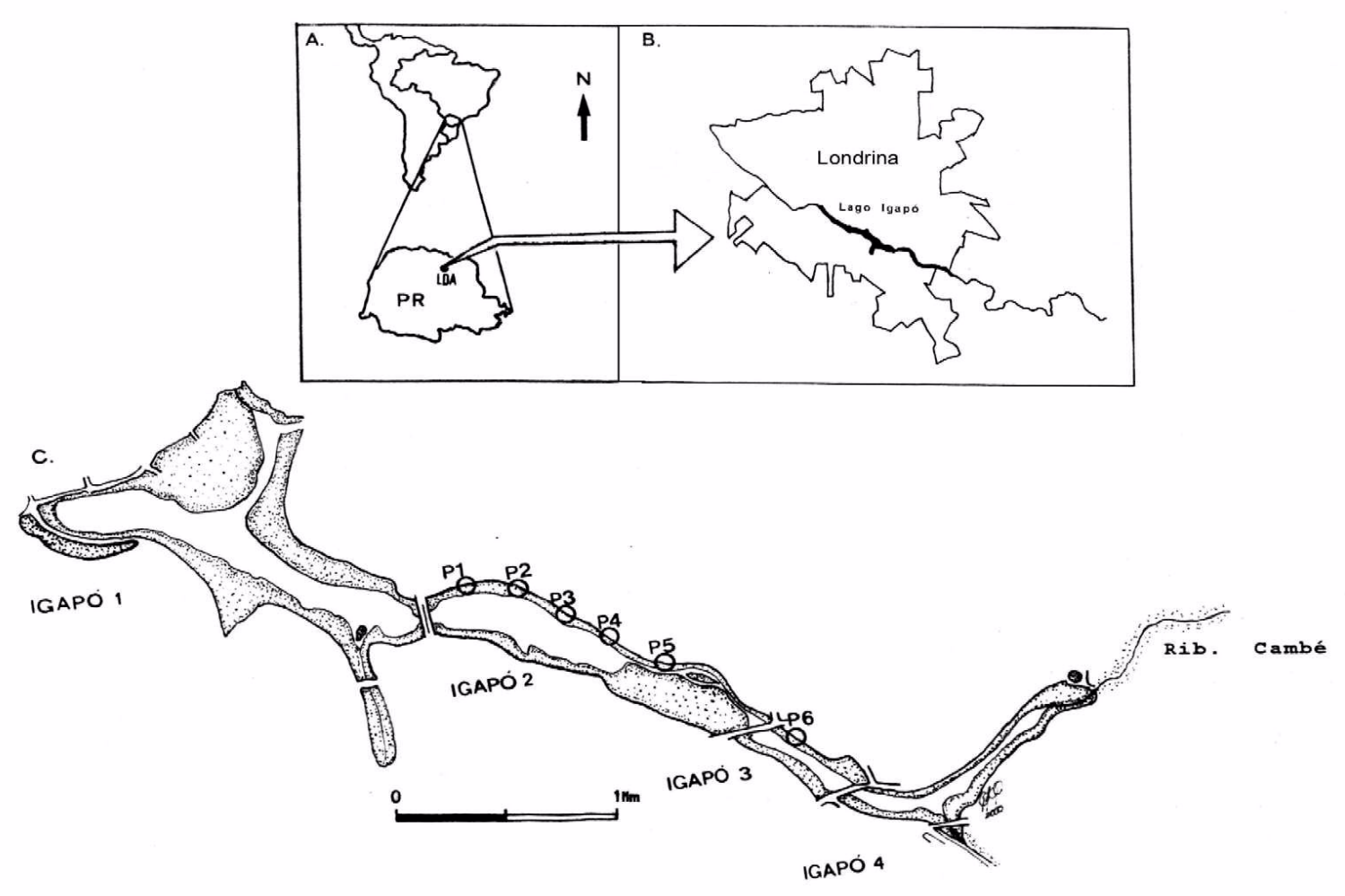

Figure 1 - A) South america, Brazil and Paraná state B) City of Londrina highlighting the Igapó lake C) Map of the Igapó Lake, Londrina, Paraná with the respective Culicidae collection point.

The Culicidae population dynamics changed according to alterations in the aquatic atmosphere, thus, in the beginning of the 80 's, Igapó lake was completely polluted and offering conditions for the development of high density of mosquitoes belonging to the Culex genus (Faria Neto and Lopes, 1981). In 1985, the same lake, then less polluted, presented high number of pond lilies, which covered good part of the water, propitiating the normal growth of Mansonia titillans (Lopes et al., 1995) in captures using human bait. However, this species was notfound in this research due to methodology used in the capture of the larvae forms and due to present aquatic macrophytes monitoring and controlling activities. From the collections of immature conducted from September 1996 to the same month in 1997, An. strode $i$ was the most abundant species $(47.81 \%)$ (Table1).

The highest population of An. strodei was found from July to September 1997 (Fig. 2 and Table 2).
A negative linear correlation was obtained between population and rainfall during the collections $(\mathrm{r}=-0.7077 ; \mathrm{p}<0.001)$.

This species was also found in high population levels in lakes in São Paulo (Corrêa, 1938), all year long in Curitiba (Lozovei and Luz, 1976) and Cambé (83.3\% ) (Lopes and Lozovei, 1995). At present research shows variation of the fauna along the time in the same environment, and the current presence of anophelines as dominant group can indicate that the environmental quality improved, therefore those culicines doesn't tolerate, in general, polluted waters. In samplinng conducted in the basin of the Aguapeí river in the Santa Alice farm, São Paulo state, Corrêa (1938) suggested that this mosquito as domestic and out of 163 collected mosquitoes, two carried malaria oocytes in the stomach. 
Table 1 - Culicidae (means) larvae collected in the Igapó Lake, Londrina - Paraná (from Sept - 1996 to Sept - 1997).

\begin{tabular}{lcccccccccccccc}
\multicolumn{1}{c}{ SPECIES } & Sep & Oct & Nov & Dec & Jan & Feb & Mar & Apr & Mai & Jun & Jul & Aug & Sep & Total \\
\hline Ad. & 21 & 10 & 9.5 & 36 & 08 & 3.5 & 02 & 9 & 1.5 & - & 1.5 & - & - & $\mathbf{1 8 5}$ \\
squamipennis & & & & & & & & & & & & & \\
Ae. terrens & - & - & 7.5 & - & - & - & - & - & - & - & - & - & - & $\mathbf{1 5}$ \\
An. albitarsis & - & - & - & - & - & - & - & 0.5 & - & - & - & - & - & $\mathbf{1}$ \\
An. brasiliensis & 04 & 02 & 1.5 & - & - & 0.5 & 0.5 & - & - & - & - & 02 & 0.5 & $\mathbf{1 8}$ \\
An. evansae & 02 & 02 & 2.5 & 06 & - & - & 01 & 01 & 0.5 & - & 0.5 & 02 & - & $\mathbf{3 3}$ \\
An. galvaoi & - & - & - & 0.5 & - & - & - & - & - & - & - & 03 & - & $\mathbf{4}$ \\
An. oswaldoi & 04 & 4.7 & 02 & 02 & - & - & 1.5 & 03 & 2.5 & - & - & 03 & 1.5 & $\mathbf{4 6}$ \\
An. strodei & 18 & 14.3 & 18.5 & 2.5 & 01 & 02 & 16.5 & 23 & 12 & 04 & 38.5 & 108 & 30 & $\mathbf{4 6 0}$ \\
An. argyritarsis & 1.0 & 1.4 & - & 01 & - & - & 0.5 & - & - & - & 0.5 & - & 0.5 & $\mathbf{1 0}$ \\
Cx.. (Mel.) spp. & - & 3.0 & 10 & 02 & 06 & 0.5 & 6.5 & 8.5 & 1.5 & - & 01 & 03 & 1.5 & $\mathbf{8 1}$ \\
Culex sp & - & - & - & - & - & - & - & 0.5 & - & - & - & - & - & $\mathbf{1}$ \\
Cx.. bidens & - & - & - & - & - & - & 0.5 & - & - & - & - & - & - & $\mathbf{1}$ \\
Cx.. coronator & - & 1.3 & - & - & - & - & 4.5 & - & - & - & 0.5 & 10 & 01 & $\mathbf{2 6}$ \\
Cx.. eduardoi & - & - & - & - & - & - & 3.5 & - & - & - & - & - & - & 7 \\
Cx.. mollis & - & - & - & - & - & 0.5 & 22 & - & - & - & - & 04 & - & $\mathbf{4 9}$ \\
Cx.quinquefasci & - & 01 & - & - & - & - & 2.5 & - & - & - & - & 16 & - & $\mathbf{2 4}$ \\
ats & & & & & & & & & & & - & - & - & $\mathbf{1}$ \\
Ur. geometrica & - & - & - & - & - & - & 0.5 & - & - & - & - & - \\
\hline \multicolumn{1}{r}{ Total } & $\mathbf{5 0}$ & $\mathbf{1 1 9}$ & $\mathbf{1 0 3}$ & $\mathbf{1 0 0}$ & $\mathbf{1 5}$ & $\mathbf{1 4}$ & $\mathbf{1 2 4}$ & $\mathbf{9 1}$ & $\mathbf{3 6}$ & $\mathbf{4}$ & $\mathbf{8 5}$ & $\mathbf{1 5 1}$ & $\mathbf{7 0}$ & $\mathbf{9 6 2}$ \\
\hline
\end{tabular}

*The genera were abbreviated according to Reinert, 1975.

Table 2 - Number of mosquitoes larvae (means) for the three most collected species of in the Igapó Lake - Londrina Paraná (form Sept - 1996 to Sept - 1997).

\begin{tabular}{|c|c|c|c|}
\hline Months & $\begin{array}{c}\text { Anopheles } \\
\text { Strodei }\end{array}$ & $\begin{array}{c}\text { Culex } \\
\text { (Mel.) spp. }\end{array}$ & Aedeomyia squamipennis \\
\hline Sep & $18.0^{+} \mathrm{Ba}^{*}$ & $0.71 \mathrm{Ab}$ & $4.64 \mathrm{ABa}$ \\
\hline Oct & $14.3 \mathrm{Ba}$ & $1.73 \mathrm{Aa}$ & $3.23 \mathrm{ABa}$ \\
\hline Nov & $18.5 \mathrm{Ba}$ & $3.03 \mathrm{Aa}$ & $3.03 \mathrm{ABa}$ \\
\hline Dec & $2.50 \mathrm{Bb}$ & $1.55 \mathrm{Ab}$ & $6.04 \mathrm{Aa}$ \\
\hline Jan & $1.00 \mathrm{Ba}$ & $2.55 \mathrm{Aa}$ & $2.92 \mathrm{ABa}$ \\
\hline Feb & $2.00 \mathrm{Ba}$ & $0.97 \mathrm{Aa}$ & $1.72 \mathrm{ABa}$ \\
\hline Mar & $16.5 \mathrm{Ba}$ & $2.19 \mathrm{Aa}$ & $1.41 \mathrm{ABa}$ \\
\hline Apr & $23.0 \mathrm{Ba}$ & $2.94 \mathrm{Aa}$ & $2.96 \mathrm{ABa}$ \\
\hline May & $12.0 \mathrm{Ba}$ & $1.29 \mathrm{Aa}$ & $1.29 \mathrm{ABa}$ \\
\hline Jun & $4.00 \mathrm{Ba}$ & $0.71 \mathrm{Aa}$ & $0.71 \mathrm{Ba}$ \\
\hline Jul & $38.5 \mathrm{Aba}$ & $1.14 \mathrm{Ab}$ & $1.29 \mathrm{ABb}$ \\
\hline Aug & 108Aa & $1.87 \mathrm{Ab}$ & $0.71 \mathrm{Bb}$ \\
\hline Sep & $30.0 \mathrm{Aba}$ & $1.29 \mathrm{Ab}$ & $0.71 \mathrm{Bb}$ \\
\hline
\end{tabular}

${ }^{+}$Original averages, for the test data, were transformed in $\mathrm{x}+0,5$ roots.

* Similar capital letters in the column, and lower case letters on the line do not differ from each other by the Tukey test at the $5 \%$ level of significance.

$\mathrm{CV}=51.72 \%$

Based in that succession, and in the registered amount, it can admited that so much for the biodiversity as for the density population doesn't make itself necessary to indicate control measures. Besides the abundant anopheline is low competent in the trasmission of the malaria and it would be worthless the possibility of autochthonous establishment of the disease. Lopes and Lozovei
(1996), collected an abundance of An. strodei from September to December 1988, and from May to June 1989 from the of the São Domingos stream. The authors suggested that this species became more frequent in collections along the São Domingos stream, $83.3 \%$ of the individual total collection, with population peaks in April, May and June, the latter showing the largest population 
growth (Lopes and Lozovei, 1995). The authors suggested that Anopheles (Nyssorhynchus) species go through winter in larvae form, causing an above the annual average accumulation in population density in the month of September. This finding agreed with the data collected at the Igapó Lake (Table 2 - Fig. 2). From the 571 captured anophelines, Anopheles argyritarsis, Robineau - Desvoidy 1827; Anopheles braziliensis, (Chagas) 1907; Anopheles evansae, (Brethes) 1926; Anopheles galvaoi, Causey, Deane and Deane 1943, Anopheles oswaldoi, and Anopheles albitarsis, Lynch Arribalzaga 1878 were the least frequent contributing to $19.4 \%$ of the capture total. These results indicate little acceptance of this habitat type by the mosquitoes of these species.

Aedeomyia squamipennis was the second most abundant species, however, its average did not differ from the Culex (Melanoconium) spp. (Table 2). Lopes and Lozovei, (1995) found a predominance of this species ( $48 \%$ ) in relation to the total of collected Culicidae. However, 99.7\% of the Aedeomyia were captured in the São Domingos stream dam. In adults of this species, viruses of the Gamboa serogroup group were isolated by Calisher et al. (1981) in samples collected in Honduras. The same virus was present in mosquitoes of this species collected in Panama, Ecuador and Argentina (Calisher et al., 1988). This mosquito did not present antropofilic according to Lopes and Lozovei (1996), who used human baits close to a larvae of this species breeding site. No samples of this species were found. Low levels of $A d$.

squamimpennis collected with human baits were also mentioned by Klein et al. (1992) and Quintero et al. (1996). However, larvae of this species were found in large populations in dams with vegetation.

Lozovei and Luz (1976) collected all year long large populations of Ad. squamipennis in dams in the outskirts of Curitiba city whereas in the other dams and swamps captures were carried out in the spring and summer only. Lopes and Lozovei (1995) found this species in larger population density from October to January with an evident population fluctuation.

These data agreed with those observed in the Igapó lake, once this species presented a significant positive linear correlation with temperature ( $\mathrm{r}=0.5816 ; \mathrm{p}<0.05)$ (Fig. 2).
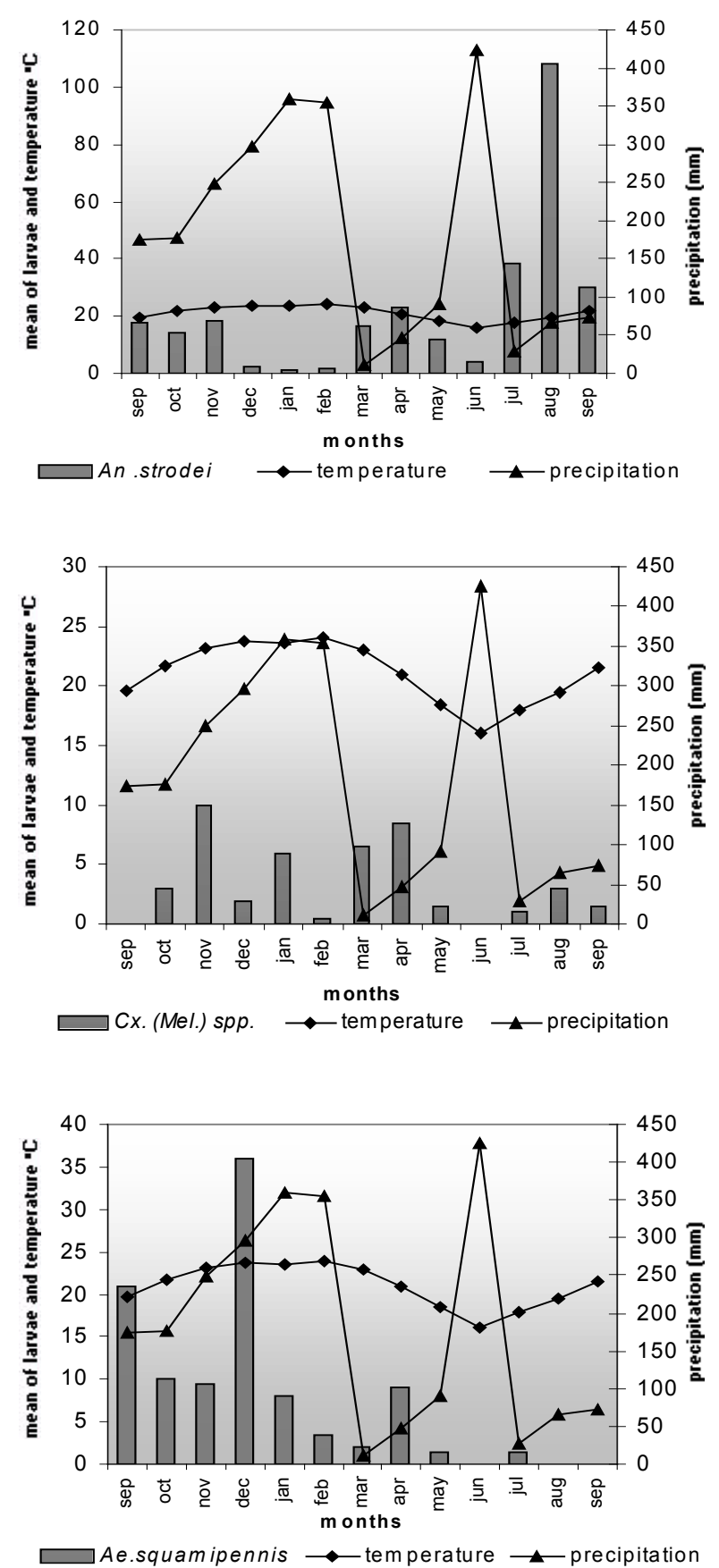

Figure 2 - Flutuacting population (monthly average) of the tree more frequent species, collected in Igapó lake, Londrina, Paraná, related to temperature and rainfall.

This mosquito was not found in the months of June, August and September, 1997. It also presented population peaks in the months of September and December, 1996 (Fig. 2).

Many Culicidae belonging to the Melanoconium subgenus was related to the enzootic transmission 
of several arboviroses (Dutra et al., 1996) . This subgenus was also abundant in the Igapó lake. This group has been found by several authors as Klein et al. (1992), Consolim et al. (1993); Lopes and Lozovei (1995); Lopes et al. (1995), Lopes and Lozovei 1996 and Quintero et al. (1996). In this study, the $C x$. (Melanoconium) spp. appeared constantly with low population oscillation along the years (Fig. 2 and Table 2). However, Lopes and Lozovei (1996) collected this species more frequently in January. Despite being potential vectors of diseases, they presented themselves as species of wild behavior (Lopes and Lozovei, 1995). The Culex (Culex) species collected in this study were of low frequency. This result was expected since these species prefer recipients or shallow puddles for reproduction.

Aedes terrens is well known for reproducing in small breeding sites and in tree holes (Davis 1944; Lourenço-de-Oliveira et al., (1986), which may be the cause of its low frequency in the type of habitat studied. As for the Uranotaenia geometrica, one sample only was collected in the month of March, showing its low adaptability to sunny ponds, located in urban areas, as it is the case of Igapó lake. Larvae of this species are frequently found associated with pond lilies Eichornia sp. A. Rich. (Lane, 1943).

Based on the results obtained, artificial lakes with aquatic vegetation and direct heatstroke seemed to favor the procreation of Anopheles.

\section{CONCLUSIONS}

Artificial lakes located in urban areas with aquatic vegetation and direct heatstroke were characterized as Culicidae breeding sites, especially of the Anopheles species. An. strodei was shown as the most adaptable to antropic conditions and it was the most abundantly found species. An. albitarsis, An. galvaoi, Cx. bidens and Ur. geometrica were sporadic species, being characterized as little adapted to this type of environment.

Appropriate handling, as the removal of the aquatic macrophytes, the cleaning of the margins and the absence of pollutants have contributed to the control of Culicidae in artificial lakes. Management is recommended to the lake, being adopted as an indicator of larval density and also, to implant a surveillance programme being attentive for the complaints of the population of the influence area, referring to the situation of uncomfortability.

\section{AKNOWLEDGEMENTS}

The authors wish to thank Paulo Cypriano Pereira from the State University of Londrina Center of Biological Science, Paraná for drawing the maps, Dra. Inês Cristina de Batista Fonseca from the State University of Londrina Center of Agrarian Sciences, Paraná, for helping with the statistics and Dr. Maurício Ursi Ventura from the State University of Londrina for revising the article.

\section{RESUMO}

O lago Igapó é um conjunto de quatro represas localizadas na área urbana de Londrina, Paraná, Brasil, com condições propícias para procriação de culicídeos. A presente pesquisa teve como objetivo verificar a culicideofauna de imaturos neste lago, monitorando possíveis vetores de agentes patogênicos. Durante um ano coletou-se 962 imaturos que se distribuíram nos seguintes gêneros: Anopheles (59,36\%), Culex (19,65\%) Aedeomyia $(19,23 \%)$ Aedes $(1,50 \%)$, and Uranotaenia $(0,10 \%)$. As espécies mais abundantes foram Anopheles strodei, Aedeomya squamipennis, Culex. (Melanoconium) spp., Culex mollis, Anopheles oswaldoi, Anopheles evansae, Culex coronator, Culex quinquefasciatus, Anopheles argyritarsis e Aedes terrens respectivamente. An. strodei, prevaleceu com grandes médias populacionais de Julho a Setembro, mostrando uma correlação linear negativa em relação a precipitação. $A d$. squamipennis, mostrou uma correlação linear positiva com a temperatura, com baixos índices populacionais nos meses de Junho, Agosto e Setembro de 1997. As populacões de $C x$. (Melanoconium) spp. foram constantes ao longo do ano. Conclui-se que lago localizado na área urbana com condições para o desenvolvimento de culicídeos, podem trazer problemas para a qualidade de vida da população, e recomenda-se medidas para melhoria da qualidade destes ecossistemas. 


\section{REFERENCES}

Calisher, C. H.; JOHN, S. L.; Gustavo, J.; D. B. F.; Thomas, P. M.; Ernesto, G. V.; Marta, S. S.; G. S. B. and Werner, L. J. (1981), Viruses isolated from Aedeomyia squamipennis mosquitoes collected in Panama, Ecuador and Argentina establisment of the Gamboa serogroup. Am. J. Trop. Med. Hyg., 30 : (1), 219-223.

Calisher, C. H.; John, S. L. and W. D. S. (1988), Brus Laguna virus, a Gamboa Buny a virus from Aedeomyia squamipennis collected in Honduras. Am. J. Trop. Med. Hyg., 39 : (4), 406-408.

Consolim, J.; Ennio, L.; Nilson, J. M. P. and Pedro, B. T. (1991), O Anopheles (Nyssorhynchus) darlingi Root, 1926 e a malária no lago de Itaipu, Estado do Paraná, Brasil: Uma revisão de dados. Arq. Biol. Tecnol., 34 (2), 263-286.

Consolim, J.; Nilson, J. M. P. and Ennio, L. (1993), Culicideos (Diptera, Culicidae) do lago de Itapu, Paraná, Brasil. I. Município de Foz do Iguaçu. Acta Biol. Par., 22 : (1-4), 83-90.

Corrêa, R. R. (1938), O Anopheles (N) strodei Root, 1926 como provável vetor de malária. Revista de Biologia e Hygiene, 9 : (2), 104-109.

Davis, E. D. (1944), Larval habitats of some Brazilian mosquitoes. Rev. Entomol., 15 : (1/2), 221-235.

Dutra, A. P.; Délsio, N.; Rosa, M. T.; José, M. S. B.; Regiane, M. T. M.; Paulo, R. U. and Antonio, I. P. C. (1996), Mosquitos (Diptera, Culicidae) da Reserva Estadual de Pedro de Toledo (Juquitiba, S.P., Brasil). Rev. bras. Ent., 40 : (3/4), 375-378.

Faria, A .A .N. and José, L. (1981), Lago Igapó como um potencial criadouro de Culicidae. Semina, 7 : (2), 169.

Guimarães, A. E.; Rubens, P. M.; Catarrina, M. L.; Jerônimo, A. and Carla, G. (1997), Prevalência de Anophelinos (Diptera: Culicidae) no crepúsculo verspertino em áreas da usina hidrelétrica de Itaipu, no município de Guaíra, Estado do Paraná, Brasil. Mem. Inst. Oswaldo Cruz, 92 : (6). 745-754.

Klein, T. A.; José, B. P. L. and Amazonia, T. T. (1992), Seasonal distribution and diel bitting patterns of Culicine mosquitoes in Costa Marques, Rondônia, Brazil. Mem. Inst. Oswaldo Cruz, 87 : (1), 141-148.

Lane, J. (1943), Sobre o gênero Uranotaenia (Diptera, Culicidae, Culicini). Rev. Entomol., 14 : (1/2) 137-161.

Lopes, J. and Ana, L. L. (1995), Ecologia de mosquitos (Diptera: Culicidae) em criadouros naturais e artificiais de área rural do Norte do Estado do Paraná, Brasil. I-Coletas ao longo do ribeirão. Rev. Saúde Pública, 29 : (3), 183-191.
Lopes, J. and Ana, L. L. (1996), Ecologia de mosquitos (Diptera: Culicidae) em criadouros naturais e artificiais de área rural do Norte do Estado do Paraná, Brasil. II - Coletas com isca humana. Rev. bras. Zool., 13 : (3), 585-596.

Lopes, J.; Francisco, J. A. O.; Vania, D. R. B. O. and Maria, A. P. T. (1995), Alterações na densidade populacional e diversidade de Culicidae (Diptera) na área urbana do município de Londrina, Estado do Paraná, sul do Brasil em consequência e modificações ambientais. Semina, 16 : (2), 238-243.

Lozovei, A. L. and Ennio. L. (1976), Diptera Culicidae em Curitiba e arredores. I. Ocorrência. Arq. Biol. Tecnol., 19, 25-42.

Lourenço-de-Oliveira, R.; Heyden, R.; Silva, T. F. (1986), Alguns aspectos da ecologia dos mosquitos (Diptera, Culicidae) de uma área de planície (Granjas Calábria), em Jacarepaguá, Rio de Janeiro. Mem. Inst. Oswaldo Cruz, 81 : (3), 265-271.

Quintero, L. O.; Bedsy, D. T. and Wanderli, P. T. (1996), Biologia de anofelinos amazônicos. XXI. Ocorrência de espécies de Anopheles e outros culicídeos na área de influência da hidrelétrica de Balbina - cinco anos após o enchimento do reservatório. Acta Amazonica, 26 : (4), 281-296.

Reinert, J. F. (1975), Mosquito Generic and Subgeneric Abbreviations (Diptera: Culicidae). Mosquito Systematics, 7 : (2), 105-110.

Tadei, W. P. and Bedsy, D. T. (2000), Malaria vectors in the Brazilian Amazon: Anopheles of the subgenus Nyssorhynchus. Rev. Inst. Med. Trop., 42 : (2), 87-94.

Received: July 18, 2001; Revised: October 05, 2001; Accepted: January 18, 2002. 